\title{
The legitimacy and legitimation of international organizations: introduction and framework
}

\author{
Jonas Tallberg ${ }^{1} \cdot$ Michael Zürn ${ }^{2}$
}

Published online: 5 January 2019

(C) Springer Science+Business Media, LLC, part of Springer Nature 2019

\begin{abstract}
While legitimacy dynamics are paramount in global governance, they have been insufficiently recognized, conceptualized, and explained in standard accounts of international cooperation. This special issue aims to advance the empirical study of legitimacy and legitimation in global governance. It engages with the question of when, how, and why international organizations (IOs) gain, sustain, and lose legitimacy in world politics. In this introduction, we first conceptualize legitimacy as the belief that an IO's authority is appropriately exercised, and legitimation and delegitimation as processes of justification and contestation intended to shape such beliefs. We then discuss sources of variation in legitimation processes and legitimacy beliefs, with a particular focus on the authority, procedures, and performances of IOs. Finally, we describe the methods used to empirically study legitimacy and legitimation, preview the articles of the special issue, and chart next steps for this research agenda.
\end{abstract}

Keywords Legitimacy · Legitimation · International organizations · Authority · Performance $\cdot$ Prodecure $\cdot$ Audience $\cdot$ Narratives

Legitimacy is central for international organizations (IOs) to make a difference in world politics. While states have granted IOs more political authority in recent decades, in the expectation that they can help solve pressing problems and shape practices, IOs' longterm capacity to deliver is conditioned on their legitimacy in the eyes of governments and citizens. As Buchanan and Keohane $(2006,407)$ put it, "[ $t]$ he perception of legitimacy matters, because, in a democratic era, multilateral institutions will only thrive if they are viewed as legitimate by democratic publics." In this respect, IOs are not different from other organizations in political life (Parsons 1960; Meyer and Rowan 1977; Dahl and Lindblom 1992).

Jonas Tallberg

jonas.tallberg@statsvet.su.se

1 Stockholm University, Frescativägen, 11419 Stockholm, Sweden

2 WZB Berlin Social Science Center, Reichpietschufer 50, 10785 Berlin, Germany 
First, legitimacy influences whether IOs remain relevant as the focal arenas for states' efforts to coordinate policies and solve problems. In a world of forum shopping and organizational turf battles, legitimacy is a crucial resource for IOs wishing to fend off multilateral competitors and unilateral action (Morse and Keohane 2014; Zelli 2018). The dwindling legitimacy of the International Criminal Court (ICC) in the eyes of many African governments is widely seen as a challenge for the court's relevance, leading to demands for the establishment of an African court. Conversely, states actively seek the endorsement of the United Nations (UN) Security Council because it lends international legitimacy to their actions, thereby further reaffirming its stature.

Second, legitimacy affects the capacity of IOs to develop new rules and norms. When IOs suffer from poor legitimacy among elites and citizens, this makes it more difficult to gain governments' support for ambitious policy goals and to secure ratification of new agreements (Putnam 1988; Martin 2000; Sommerer and Agné 2018). For instance, successive rejections of new European Union (EU) treaties by citizens in several countries have put plans for further large-scale reforms on the back burner. Most recently and dramatically, Britain voted to leave the EU, illustrating the importance of popular legitimacy for states' active engagement in international cooperation, but also effects of legitimacy crises for IO policy making.

Third, legitimacy influences IOs' ability to secure compliance with international rules and norms. In general, legitimacy is a much cheaper means to secure compliance than coercion (Lindblom 1977). Moreover, since few IOs command the coercive power to compel state and non-state actors to comply, legitimacy is particularly important in global governance (Franck 1990; Hurd 1999). Evidence from a broad range of regulatory domains and levels suggests that legitimacy contributes to compliance, even when adjustment costs are high (Chayes and Chayes 1998; Zürn and Joerges 2005). Conversely, low legitimacy of an IO can hurt the respect for international rules. For instance, the declining legitimacy of the World Trade Organization (WTO) in the US government under President Donald Trump, and among regional powers such as Brazil and India, threatens to undermine the respect for the multilateral trade regime.

Finally, the legitimacy of IOs also speaks to fundamental normative concerns about global governance. If IOs lack legitimacy in society, this contributes to a democratic deficit in global governance (Dahl 1999; Zürn 2000; Held and Koenig-Archibugi 2005). As political authority increasingly shifts to the global level, democracy's preservation requires that IOs both are structured in accordance with democratic principles and are perceived by citizens as legitimate systems of governance. While the EU, for instance, may conform well to some democratic standards, it would be normatively problematic if its decisions had to be enforced against peoples that lack faith in its legitimacy. Indeed, one of the most prominent arguments put forward by right-wing populists in Europe is about the illegitimate encroachment of the EU on popular sovereignty.

Yet, despite these effects of legitimacy for IOs' role in world politics, we still know little about the factors and processes that drive and shape legitimacy beliefs. While legitimacy dynamics are paramount in global governance today, they are insufficiently recognized, conceptualized, and explained in standard accounts of international cooperation. The scant attention to these issues in international relations (IR) contrasts with their central position in other sub-disciplines of political science and other fields in the social sciences. The legitimacy and legitimation of political institutions is a topic with a long pedigree in comparative politics, political theory, sociology, and psychology, 
involving classic contributions by Weber (1922/1978), Arendt (1956), Lipset (1960), Easton (1975), Habermas (1976), Tyler (1990), and Beetham (1991). This trajectory has continued into present times. For instance, comparative politics has featured vibrant debates on legitimacy, trust, and public opinion in relation to courts, legislatures, and public administrations (e.g., Caldeira and Gibson 1992; Norris 2011; Uslaner 2002; Rothstein 2005; Booth and Seligson 2009).

The aim of this special issue is a better understanding of when, how, and why IOs gain, sustain, and lose legitimacy in world politics. We conceptualize legitimacy as beliefs of audiences that an IO's authority is appropriately exercised, and legitimation as a process of justification and contestation intended to shape such beliefs. We discuss sources of variation in legitimacy and legitimation, with a particular focus on the authority, procedures, and performance of IOs. We probe some of the propositions by empirically mapping and explaining patterns in legitimation processes and legitimacy beliefs across organizations, countries, and time. While we do not directly analyze the consequences of legitimacy, the implications of our research bolster the assumption that legitimacy is consequential in global governance.

We approach legitimacy and legitimation as observable empirical phenomena. Expressed in terms of a common distinction, our interest is primarily legitimacy in the sociological sense - actors' perception of an institution's authority as appropriately exercised - rather than legitimacy in the normative sense - an institution's exercise of authority as rightful and worthy of recognition based on its conformance to principles such as justice, public interest, and democracy. Yet we recognize that the perceived legitimacy of IOs is likely to be influenced by normative principles about rightful rule, and consider it an important task to explore the relationship between normatively justified sources of legitimacy and legitimacy beliefs about IOs.

Our framework distinguishes between IOs' procedures for making decisions and performance in developing effective policy as the principal sources of legitimacy. As IOs have gained in political authority, the procedural and performance standards they have to meet to remain legitimate have increased as well. Efforts to legitimize or delegitimize IOs invoke these standards to affect audiences' legitimacy beliefs positively or negatively. The framework theorizes the relationship between the institutional features of IOs (authority, procedure, and performance), the legitimation process (intensity, tone, and narratives), and the legitimacy beliefs of audiences (constituencies and observers).

Our primary focus is IOs, by which we mean formal, multilateral, and bureaucratic arrangements established to further cooperation among states. Concentrating on IOs means giving less attention to other forms of authority in global governance. Yet there is nothing inherent in our approach to legitimacy and legitimation that restricts it from being extended to private, bilateral, or informal arrangements. Indeed, some contributions to this special issue explicitly analyze legitimacy and legitimation in relation to a broader set of global governance institutions.

Putting the legitimacy and legitimation of IOs center stage allows us to engage with some of the critical questions confronting the study and practice of global governance: Are we witnessing a growing authority-legitimacy gap that threatens the long-term prospects of global governance? Are IOs increasingly evaluated by citizens on democratic criteria, rather than their capacity to deliver substantive benefits? How easily influenced are citizens' legitimacy beliefs by elite practices of legitimation and delegitimation? Can institutional reforms of IOs in recent years be understood as a legitimation strategy? Do elites and citizens in the emerging powers hold different 
legitimacy beliefs than their counterparts in North America and Europe, and with what implications for the future of global governance? While we do not tackle all of these empirical questions in this special issue, we claim that our framework is useful for studying them.

The overarching contribution of this special issue is to advance the empirical study of legitimacy and legitimation in global governance. It marries a classic concept in social theory with advanced scientific methods and rich empirical data. More specifically, the contribution is three-fold. First, we offer a theoretical framework for studying legitimacy and legitimation in global governance. The framework conceptualizes legitimacy as a dependent variable and legitimation as a mediating variable, both affected by perceived properties of the IOs exercising authority. Contributors to this special issue all build upon this framework. Second, we employ advanced methods in the study of public opinion, political behavior, and political communication to analyze legitimacy and legitimation. The methods include survey experiments, field experiments, content analysis, and case studies, and make use of original data collected for the contributions to this special issue. Advancements in methods make it possible to study complex concepts such as legitimation and legitimacy in a systematic fashion. Third, we empirically cover legitimacy issues and legitimation processes in a broad set of IOs, drawn from different issue areas, performing different policy functions, and with memberships that vary regarding political systems and power relations.

The remainder of this introduction is organized in six parts. The first section briefly reviews existing scholarship on legitimacy and legitimation in global governance. The second section introduces our conceptualization of legitimacy and legitimation. The third section outlines a framework for explaining legitimacy and legitimation. The fourth section describes methods for empirically studying legitimacy and legitimation. The fifth section previews the articles of the special issue. We conclude by discussing next steps in research on legitimacy and legitimation in global governance.

\section{The state of the art}

Legitimacy is a topic with an enduring but marginal place in the study of world politics. To begin with, several classic approaches in IR have touched on the topic of legitimacy, but primarily in the context of interstate politics. Realists have usually seen legitimacy as a means of power wielding that states exploit to advance their interests, but that is not expected to constrain their actions (Morgenthau 1948; Krasner 1999). In this vein, Carr (1946) argues that strong states can further their interests externally by cloaking them in internationally acceptable principles, while Goldsmith and Posner (2005) challenge the idea that international law possesses some inherent legitimacy that can and should restrict the actions of states.

In contrast, liberal institutionalists have viewed legitimacy more positively, highlighting its functional usefulness to the collective of states (Keohane 2006). For instance, Claude (1966) suggests that IOs fulfill an important political function of collective legitimization, while Ikenberry (2001) argues that the establishment of legitimate world orders after wars helps to reduce costs of enforcing the peace.

Constructivists have devoted more sustained attention to international legitimacy. One strand of research has examined how the legitimacy of international norms and 
laws affects state behavior by creating a "compliance pull" (Franck 1990; Hurd 1999; Risse et al. 1999; Checkel 2001). Another strand explores how states create, use, and contest the legitimacy of actors and institutions in international society, because of its importance as a resource (Clark 2005; Hurd 2007; Reus-Smit 2007; Finnemore 2009). A third strand theorizes legitimacy in relation to authority in global governance, conceiving of IOs as "autonomous sites of authority" whose influence results from "the legitimacy of the rational-legal authority they embody" (Barnett and Finnemore 1999, 707; see also Hurd 2007; Avant et al. 2010).

With the rise of global governance, interest in legitimacy has broadened. This change has been driven by the dual recognition that global governance nowadays involves elements of authority and hierarchy that put issues of legitimacy center stage, and that global governance reaches behind borders and makes citizens an independent constituency of IOs. Yet most of this research has been normative in orientation. Drawing on political theory, scholars have debated the normative standards that should be used when evaluating IOs and offered alternative assessments of their legitimacy (e.g., Dahl 1999; Zürn 2000; Held and Koenig-Archibugi 2005; Buchanan and Keohane 2006). This literature has thus been driven by a different set of questions than those explored in this special issue.

Only recently has the legitimacy of IOs emerged as a distinct topic of positive empirical research. First, some studies have sought to map and explain the legitimacy of IOs through public opinion, exploring what factors shape citizens' legitimacy beliefs (Norris 2009; Johnson 2011; Ecker-Ehrhardt 2012; Voeten 2013; Dellmuth and Tallberg 2015; Schlipphak 2015). Second, some contributions have addressed how IOs are legitimized or delegitimized through practices aimed at boosting or undermining the legitimacy of these organizations (Steffek 2003; Bernstein 2011; Brassett and Tsingou 2011; Zaum 2013; Binder and Heupel 2015).

We build on these recent efforts to address three deficits. First, there is a need to move beyond states as the exclusive audience of IOs' legitimacy claims to systematically study the beliefs of citizens and other societal actors. Second, the empirical study of legitimacy and legitimation remains underdeveloped in comparison to existing normative treatments. Third, as this research agenda moves forward, it should build on a conceptualization that defines legitimacy as distinct from, but in close relationship to, authority and legitimation.

\section{Conceptualizing legitimacy and legitimation}

We adopt a sociological understanding of political legitimacy as beliefs within a given constituency or other relevant audience that a political institution's exercise of authority is appropriate. Legitimacy from this perspective lies with the beliefs and perceptions of audiences, not the normative goodness of an institution, although the latter may influence whether audiences regard an institution's exercise of authority as more or less appropriate. Legitimacy beliefs are the outcome of a process in which individual priors interact with justifications and challenges of political institutions. Where actors deliberately seek to make a political institution more legitimate, by boosting beliefs that its rule is exercised appropriately, we refer to legitimation. Conversely, where actors 
seek to undermine the legitimacy of a political institution by challenging the appropriateness of its exercise of authority, we speak of delegitimation.

\subsection{Legitimacy}

Legitimacy is a relational property, determined by the beliefs and perceptions of audiences about the exercise of authority (see also Hurd 2007, 7; Reus-Smit 2007, 44). We conceptualize audiences as including both state and societal actors, from government elites to ordinary citizens. When these audiences are bound by the authority of an IO, as in the case of governments and citizens in member states, we refer to them as constituencies. Legitimacy is ultimately most important in the relationship between the authorities that govern and those who are governed. When audiences are not bound by the authority of an IO, as in the case of governments and citizens in non-member states, we refer to them as observers. Observers, too, may have beliefs about the legitimacy of an authority and are therefore included in our conceptualization of audiences. Given this plurality of audiences, the legitimacy of an IO is not a constant, but it may vary across audiences and over time. An IO may enjoy high legitimacy among its constituencies, but low legitimacy among observers. Likewise, among its constituencies, an IO may enjoy high legitimacy with member governments, but low legitimacy with domestic populations. Legitimacy beliefs are usually, but not exclusively, studied through elite and public opinion, often with an individual's confidence or trust in a political institution as measurements (e.g., Caldeira and Gibson 1995; Norris 2009; Bühlmann and Kunz 2011; Voeten 2013; Dellmuth and Tallberg 2015).

In our conceptualization, legitimacy is distinct from authority. While authority refers to the recognition that an institution has the right to make decisions and interpretations within a particular area, legitimacy refers to the perception that these rights are appropriately exercised (Zürn et al. 2012, 82-88). For instance, a person may recognize the authority of the WTO as the principal forum for developing international trade law, but have little confidence in the exercise of this authority, given how decisions are made and how they impact specific communities. This analytical separation of legitimacy from authority is well anchored in parts of social theory. For instance, Weber (1922/ 1978,213 ) speaks of how every system of authority "attempts to establish and to cultivate the belief in its legitimacy" (see also Barker 2001). At the same time, authority and legitimacy are related, in so far as legitimacy only becomes an issue once an institution possesses authority. In the absence of authority, there would be no legitimacy problem. We call this connection the authority-legitimacy link, which makes legitimacy conceptually and substantively "parasitic" on authority.

In conceptualizing legitimacy and authority as distinct but related entities, we differ from some other IR theorists. Hurd (2007, 60-61), for instance, argues that an institution has authority if it is perceived as legitimate. Accordingly, an institution either has authority - in which case it is legitimate - or it has neither authority nor legitimacy: "The phrase 'legitimate authority' is redundant" (Hurd 2007, 61, fn. 116). Similarly, Lake $(2007,56)$ submits that a state has authority over another state when the subordinate state recognizes the legitimacy of the dominant state's commands. Yet only if we distinguish analytically between legitimacy and authority can we address some crucial issues confronting global governance, such as the potential emergence of a 
legitimacy gap in the aftermath of growing IO authority over recent decades. In this special issue, we will operationalize authority in institutional terms, as resulting from formal or informal delegation of authority from member states to an IO and pooling of authority in an IO through collective decision making (Hooghe et al. 2017; cf. Lake 2015).

In our understanding, legitimacy is also distinct from support. While support for a political institution may partly be driven by instrumental cost-benefit calculation, legitimacy refers to a reservoir of confidence in an institution that is not dependent on short-term satisfaction with its distributional outcomes. Legitimacy presumes that constituencies would regard an institution's exercise of authority as appropriate, even if it were to make a decision that goes against their narrow self-interest. This is how the legitimacy of courts, governments, and parliaments is commonly conceptualized (Easton 1975; Caldeira and Gibson 1995; Booth and Seligson 2009), and it makes sense to extend this notion to the legitimacy of IOs as well. So, the legitimacy of the EU Court of Justice, for instance, must rest on an appreciation of how it performs its function as a court for the collective good - not on satisfaction with the cost-benefit implications of particular judgments. In recognition of this distinction, we also avoid using support for an IO as a measurement of its legitimacy, instead relying on measures that better tap individuals' reservoir of confidence in institutions.

It may be objected that a sociological approach does not recognize the normative nature of the concept of legitimacy. This would be a misreading of our approach. Normativity has two meanings (Forst 2015, 188-189). In the first sense, it refers to socially constructed norms in society. This is how the sociological approach to legitimacy engages with normativity: by recognizing that legitimacy beliefs are formed in a context of societal norms about the appropriate exercise of authority (Suchman 1995). It is in line with this understanding that we expect citizens and elites to assess the legitimacy of IOs based on their conformance to procedural and performance norms. Normativity in the second sense refers to whether alternative standards for evaluating the legitimacy of an institution are normatively justifiable. This is how normativity is traditionally studied in political theory, which debates the best grounds for evaluating the normative qualities of an institution. Whereas the sociological approach to legitimacy does not engage in this type of analysis, its findings may feed into normative theorizing (Beetham 1991; Williams 2005; MacDonald 2012).

This double meaning of normativity suggests that sociological and normative conceptions of legitimacy may be empirically related while still analytically distinct (Keohane 2006; Bernstein 2011; Zürn 2004). If societal beliefs in the legitimacy of an institution are influenced by its conformance to normative standards, then normative and sociological legitimacy are causally related. This may often be the case, as normative standards have come to form part of the societal norm systems within which legitimacy beliefs are formed. However, conformance to normative standards is no prerequisite for sociological legitimacy. An institution such as the UN Security Council may fare poorly when evaluated against a specific normative standard, such as democracy, but still be broadly regarded as legitimate. Conversely, an institution such as the ICC may conform well to a specific normative standard, such as the rule of law, but still be regarded as illegitimate among some audiences. 


\subsection{Legitimation and delegitimation}

An important implication of the social embeddedness of legitimacy is the possibility for purposive actors to affect others' legitimacy beliefs. From this perspective, social construction does not preclude agency, but opens up spaces for strategic actors to exploit prevailing norms in attempts to shape legitimacy beliefs. While authority holders often seek to strengthen the legitimacy of their exercise of power by invoking symbols, rituals, and understandings, contestants challenge the same exercise of authority by uncovering unfair practices and outcomes or by pointing to alternative social norms (Meyer and Rowan 1977; Ashforth and Gibbs 1990). In the context of global governance, proponents of IOs engage in legitimation practices that serve to cultivate beliefs in the organizations' legitimacy. Opponents of IOs, for their part, engage in delegitimation practices that aim at undermining the perception that IOs' authority is appropriately exercised. Such practices are of interest because of their effects on legitimacy beliefs, but also in and of themselves.

Legitimation and delegitimation practices are defined by the goal to either legitimize or delegitimize an authority and thus contain intentionality. Such practices are always communicative, in the sense of conveying information about an IO intended for public consumption. More specifically, legitimation and delegitimation practices may be discursive or behavioral, directed at constituencies or observers, and sincere or manipulative in their intent (Steffek 2003; Halliday et al. 2010; Zaum 2013; Gronau and Schmidtke 2015; Stephen 2015; Bäckstrand and Söderbaum 2018). Often, discursive and behavioral practices of legitimation or delegitimation go together. An example would be an institutional reform intended to boost legitimacy that is advertised with all available means by the IO.

Discursive practices of legitimation are observable in official texts and public statements by representatives and supporters of IOs. They include public justifications of institutional reforms, framing of IO policies, use of value-laden symbols, and other rhetorical measures aimed at nurturing beliefs in the legitimacy of an IO (Dingwerth et al. forthcoming). It has become commonplace for IOs to invest in public relations, establishing offices for the branding of the organization and its policies (Ecker-Ehrhardt 2018). Attentive to public opinion, many IOs nowadays poll citizen views, are present in social media, and tailor political messages to make themselves and their policies more palatable.

Conversely, discursive practices of delegitimation are public statements involving a negative evaluation of IOs. They include non-governmental organizations (NGOs) publicly criticizing IOs for being undemocratic or for pursuing policies that make the poor worse off, as well as state representatives criticizing IOs for unfair decisionmaking procedures. One example is the efforts of NGOs to delegitimize global climate governance by claiming that its solutions are too market-oriented (Paterson 2010). Another illustration is negative public evaluations of the UN Security Council by member states, typically targeting the procedural deficiencies of the institution (Binder and Heupel 2015).

Behavioral practices of legitimation take the shape of rules, procedures, or policies put in place by IOs with the aim to strengthen legitimacy. They include the establishment of new IO bodies, reforms of existing institutions, changes to substantive policies, and the creation of public relations functions. Over recent decades, many IOs have 
adopted public information policies, accountability mechanisms, and procedures for civil society interaction, often interpreted as attempts by IOs to strengthen their legitimacy through better conformance to democratic norms (Grigorescu 2007; Tallberg et al. 2014; Heupel and Zürn 2016; Ecker-Ehrhardt 2018). Similarly, reforms that upgrade the representation and weight of emerging powers within global IOs are regularly seen as efforts to safeguard the legitimacy of these organizations beyond Europe and North America (Stephen 2015; Stephen and Zürn forthcoming).

Behavioral practices of delegitimation, for their part, are intended to mobilize and signal discontent with an IO's exercise of authority and include street demonstrations, political petitions, and social media campaigns (Gregoratti and Uhlin 2018). They can also include regime shifting and competitive regime creation by states that contest the existing multilateral order (Morse and Keohane 2014). Examples include the widespread public protests against the WTO, the International Monetary Fund (IMF), the World Bank, the G8, and the EU in the early 2000s, as well as the move by China in 2014 to set up the Asian Infrastructure Investment Bank (AIIB) in dissatisfaction with the established financial institutions.

Building on this conceptualization, we conceive of legitimation and delegitimation as varying on three logical and encompassing dimensions: intensity (strength), tone (direction), and narratives (content). Intensity refers to the number of legitimation or delegitimation events (e.g., statements, reforms, protests) within a given time frame. Legitimation intensity varies extensively across IOs, as some organizations are subject to widespread criticism and defense, while other IOs fly beneath the radar of public contention. Tone captures whether discursive and behavioral practices frame the IO in positive terms (legitimation) or negative terms (delegitimation). Narratives are patterns in the standards invoked to justify or challenge IOs. We use the term narrative in the broad sense, to refer to the evaluative content of both discursive and behavioral practices, as both contain an element of communication. All authoritative political institutions tend to develop legitimation narratives. Narratives package and prioritize a selective set of justifications. They are bound together by stories that mix reasons and deceptions to nurture the belief in legitimacy. Famous narratives in the national context are the legacy of the ruling family, religious law, democratic government, military hierarchy, collective self-esteem, and status vis-à-vis other states (Weber 1922/1978; Kojéve 2014; Forst 2015). In the context of global governance, common narratives used to legitimize and delegitimize IOs invoke participation, legality, fairness, expertise, effectiveness, gains, and tradition (Zürn 2018, 70-77).

\section{Explaining legitimacy and legitimation}

Having conceptualized legitimacy and legitimation, we now turn to our explanatory framework. What factors shape the legitimacy and legitimation of IOs? Our framework analytically starts out with institutional features of IOs and aims at understanding their effects on outcomes in a context of individual priors and societal processes.

\subsection{The framework in brief}

Our understanding of how institutional features matter for legitimacy and legitimation diverges from two alternative perspectives. According to the first, legitimacy beliefs are 
the direct product of objective institutional features of IOs that audiences care about. Based on full information about, and rational evaluation of, these features, citizens and elites hold IOs to be more or less legitimate. Most existing literature on public opinion toward IOs is based on this assumption, for instance, when hypothesizing direct relationships between the economic consequences of IOs and public opinion (e.g., Gabel 1998; Rohrschneider 2002; Chalmers and Dellmuth 2015). According to the second perspective, perceptions of legitimacy are unrelated to the institutional features of IOs. Instead, cues and heuristics determine legitimacy beliefs independent of the actual characteristics of IOs. For instance, legitimacy beliefs vis-à-vis IOs may be a byproduct of trust in national political institutions, which is used as a heuristic when assessing less familiar international institutions (Harteveld et al. 2013; Armingeon and Ceka 2014; Dellmuth and Tallberg 2015).

Different from these two perspectives, we posit that legitimacy beliefs are the outcome of a social process where individuals' priors interact with legitimation and delegitimation in producing an evaluation of IO features audiences care about. This understanding is based on the notion of bounded rationality - while it shares the first perspective's emphasis on the institutional features of IOs, it also recognizes the second perspective's point about individuals' use of cognitive shortcuts. On the one hand, we find it unlikely that legitimacy beliefs and legitimation practices are completely unrelated to IOs, their procedures, and their policies. The fact that legitimacy levels vary across IOs within the same audience suggests that there is something about IOs as such that matters. Similarly, legitimation narratives cannot diverge too far from the actual practices of IOs. On the other hand, we find it unlikely that individuals possess the knowledge, time, and capacity to rationally evaluate IO features independent of how these features are communicated, contested, and justified in public discourse. A broad literature in political psychology demonstrates that cueing, framing, and persuasion by elites and through media influence individual attitudes (Chong and Druckman 2007). Similarly, political theorists have pointed to the decisive importance of arguing and deliberation for beliefs about legitimacy (Elster 1986; Habermas 1998). Leaving analytical room for legitimation and delegitimation to shape legitimacy beliefs is therefore essential.

Building on this approach, Figure 1 summarizes the core components of our framework. It takes seriously both the features of IOs that audiences care about and the social process of legitimation. We are interested in the full causal chain linking IO features, legitimation processes, and legitimacy beliefs. For analytical purposes, we break down this chain into two relationships, captured by the two solid arrows in the

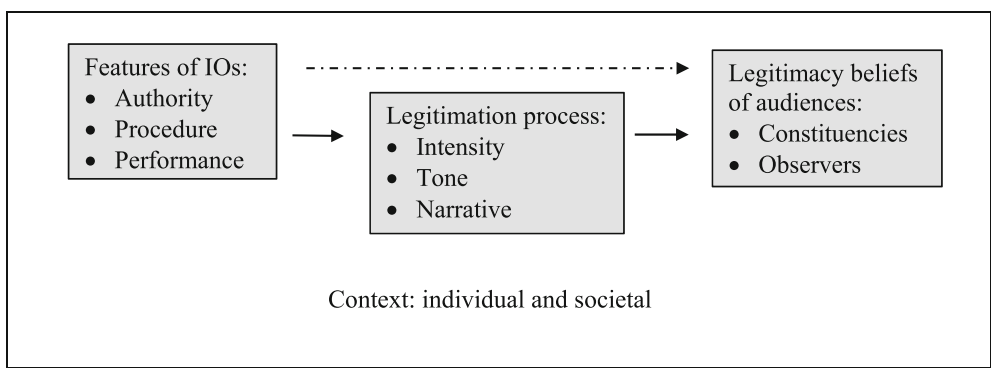

Fig. 1 Framework of analysis 
figure. While this chain likely involves feedback effects as well, we refrain from theorizing these dynamics.

First, we are interested in understanding how three central institutional features of IOs - authority, procedure, and performance - contribute to the intensity, tone, and narratives of legitimation and delegitimation. IOs make use of legitimation practices and are exposed to delegitimation attempts to varying extents. Moreover, when IOs are legitimized and delegitimized, this occurs through narratives that vary in the norms and values to which they relate. We expect this variation in the intensity, tone, and narratives of legitimation to be systematically related to IO features.

Second, we are interested in how the legitimation process shapes the legitimacy beliefs of audiences. This leads us to theorize when and how the intensity, tone, and narratives of legitimation matter for legitimacy beliefs. Recognizing that some contributions to this volume also examine the direct effects of IO features on legitimacy beliefs, bracketing the legitimation process, we consider this possibility as well.

The analytical starting point of the framework is the conferral of authority to an IO. Without authority, legitimacy is a non-issue for IOs. With authority, there is a demand for legitimacy, since IOs need the consent of the governed. An IO possesses authority when it enjoys a recognized institutional competence to make binding decisions or interpretations in the name of the collective interest (Weber 1922/1978; Raz 1990; Zürn 2018). In more concrete terms, the institutional authority of an IO is a function of delegation of authority from member states to an IO and pooling of authority in an IO through collective decision making.

The past few decades have witnessed an unprecedented growth in the authority of IOs (Hooghe et al. 2017; Zürn 2018, 107-112). On the one hand, states of unequal power have institutionalized the authority of IOs through the delegation of powers of agenda setting, decision making, implementation, and enforcement. On the other hand, states have pooled authority within IOs by increasingly shifting to forms of majority decision making that eliminate states' ability to veto international rules. At the same time, many IOs have extended their regulatory scope beyond the original functional mandates and became more intrusive.

While authority creates a demand for legitimacy, the principal institutional sources of legitimacy in our framework are the procedures through which IOs make decisions and the performance of IOs. These sources of legitimacy are grounded in social norms about the appropriate exercise of authority. While Weber (1922/1978) famously spoke of tradition and personal charisma as sources of legitimacy in the historical context of the nation state, we expect procedure and performance to be the central concerns of citizens and elites in modern global governance (see also Scharpf 1999; Hurd 2007). Procedure and performance are generic features of the policy making of political institutions and have been found to drive legitimacy beliefs in multiple contexts. ${ }^{1}$ Procedure refers to the method of policy making within IOs and directs our attention

\footnotetext{
${ }^{1}$ Our conceptualization of procedure has analytical affinities with input legitimacy (Scharpf 1999) and throughput legitimacy (Schmidt 2013). Likewise, our conceptualization of performance has analytical affinities with output legitimacy (Scharpf 1999) and pragmatic legitimacy (Suchman 1995). We consider the distinction between procedure and performance as more clear-cut than these alternatives. In order to avoid conceptual overlap between authority and procedure, we consider decision rules an element of authority (pooling), while procedure captures the process by which decisions are reached, for instance, in terms of participation, deliberation, and legality.
} 
to the process through which decisions are taken. Performance refers to the quality of the decisions made by IOs and directs our attention to the output, outcome, and impact of IO policy making.

We expect audiences to evaluate the legitimacy of IOs based on how well they perceive these organizations to conform to established procedural and performance standards, relative to the authority that IOs possess. When IOs enjoy extensive authority, they also have to meet demanding procedural and performance standards, or they will suffer from legitimacy deficits. When IOs enjoy less authority, the procedural and performance requirements they have to meet to be deemed legitimate are less demanding.

The specific standards of procedure and performance that audiences care about are multiple and partly context-dependent. While earlier work frequently associates procedure with democracy and performance with effectiveness, our framework moves beyond this narrow interpretation. Procedural standards may pertain to other qualities of the decision-making process than democracy, such as efficiency, legality, and expert involvement. Likewise, performance standards may pertain to other qualities than effectiveness, such as protection of democratic rights and processes. We therefore introduce a second axis, distinguishing between democratic and purposive qualities of procedure and performance. Qualities are democratic when they give expression to or promote core values of the democratic process. ${ }^{2}$ Qualities are purposive when they serve or promote shared ends. Democratic and purposive standards are orthogonal, not contrary, to each other. Table 1 summarizes and exemplifies these standards in a $2 \times 2$ matrix (see also Nullmeier et al. 2010).

Legitimation and delegitimation aim at shaping people's beliefs about an IO's legitimacy through discursive and behavioral practices that invoke these standards. In the framework, legitimation and delegitimation serve both as dependent variables - when seeking to explain why IOs are subject to legitimation of varying intensity, tone, and evaluative content - and as mediating variables - when seeking to explain legitimacy beliefs.

Finally, these effects take place in a context of individual and societal factors that may condition these relationships. However, rather than increase the specificity of the framework further, we note that legitimacy and legitimation are shaped through complex processes and invite the empirical contributions to this special issue to further theorize and assess such contextual factors. Earlier research on public opinion toward IOs suggests that a broad range of individual characteristics may matter for legitimacy beliefs, among them, political knowledge, social identity, economic standing, and personal values (Caldeira and Gibson 1995; Norris 2000; Hooghe and Marks 2005; Dellmuth 2018). Likewise, it is plausible that societal factors, such as political regime, economic development, and national culture, affect how institutional features of IOs shape legitimation patterns and legitimacy beliefs (Inglehart and Welzel 2005; Eisentraut 2016; Scholte and Tallberg 2018; Scholte 2018).

In the remainder of this section, we expand on the central explanatory components of this framework - authority, procedure, performance, and process - theorizing how these factors may affect the legitimacy and legitimation of IOs.

\footnotetext{
2 This conceptualization is based on an understanding of democracy that considers different distributive outcomes as compatible with the democratic process as long as the necessary resources needed for participation are provided to all (see Dahl 1989; Habermas 1996).
} 
Table 1 Institutional standards of legitimacy

\begin{tabular}{lcc}
\hline & Democratic & Purposive \\
\hline Procedure & $\begin{array}{c}\text { Participation; accountability, } \\
\text { deliberation; transparency } \\
\text { Protection of rights; protection of } \\
\text { the democratic process }\end{array}$ & Expert advice; efficiency; legality \\
& $\begin{array}{c}\text { Problem solving; collective welfare } \\
\text { gains; distributive fairness }\end{array}$ \\
\hline
\end{tabular}

\subsection{Authority}

We expect the authority of IOs to matter for legitimation practices and legitimacy beliefs. This expectation builds on the notion that international authority challenges the sovereignty and autonomy of nation states - the traditional locus of legitimate authority for citizens and elites (Lake 2010). As IOs are conferred greater authority, legitimacy deficits can arise, unless this new authority is accompanied by effective legitimation through procedures and performances that generate a flow of positive legitimacy beliefs. The EU is often said to offer an illustration of this logic (Banchoff and Smith 1999; Hooghe and Marks 2009; de Wilde and Zürn 2012). The greater the authority of the EU, the more pronounced its legitimacy problems have become, reflected in poor citizen satisfaction, low turnouts in European elections, and rejections of new EU treaties in national referenda. This argument counters the alternative view that authority is fully endogenous to legitimacy. In this view, governments would only confer authority on IOs if they consider them legitimate. Yet the relationship between authority and legitimacy varies over time and the authority of IOs often evolves beyond the intentions of governments at the contractual moment (Hawkins et al. 2006; Johnson 2014). Moreover, the legitimacy of IOs is not only a question of legitimacy among governments, but also of legitimacy within affected societies.

We also expect the authority of IOs to affect patterns of legitimation and delegitimation. Since authority relationships in global governance are relatively young, they cannot build exclusively on tradition, habituation, and mindless obedience. Rather, they involve an element of reflection and must be actively entertained (Zürn 2018; see also Bogdandy et al. 2010). For instance, deference toward the authority of the ICC or the IMF regularly contains an element of reflection. In this sense, IOs are dependent on open and active legitimation, and can be expected to put forward justifications for their authority. Conversely, the element of reflection opens up space for contestation of IOs' authority.

IOs that possess higher levels of authority can therefore be expected to engage in selflegitimation to a greater extent than IOs with lower levels of authority. By the same token, we could expect an increase over time in the intensity of legitimation by IOs, reflecting their growing political authority over recent decades. Yet this rise in international authority should also lead to growing contestation of IOs, to the extent that these organizations cannot draw on sufficient stocks of legitimacy. Such trends have been documented by several researchers in recent years (Zürn et al. 2012; Rixen and Zangl 2013).

We also anticipate differences in the type of authority to matter for legitimation patterns (Lenz et al. 2015). Task-specific IOs, such as the International Atomic Energy Agency (IAEA) and the International Whaling Commission (IWC), reflect attempts at 
parsing the problems confronting states into discrete, functional pieces. They have a narrow policy scope and are often not based on a shared sense of community. Such IOs may be more likely to legitimize their activities with reference to purpose, invoking expertise, efficiency, and problem solving. In contrast, general-purpose IOs, such as the EU and the African Union (AU), serve as general governance systems, not unlike national governments, for the manifold of problems that confront their member states. They have a broad policy mandate and are often rooted in a shared (regional) community. Such IOs may be more likely to legitimize themselves with reference to democratic standards, such as participation, transparency, and rights protection.

\subsection{Procedure}

Procedure as a source of legitimacy received early attention in Weber's (1922/1978) notion of rational-legal legitimacy, which stressed properly administered rules by properly appointed authorities. Today, this notion features prominently in the emphasis on democratic and purposive procedural standards, such as participation, transparency, legality, and impartiality. In this vein, it is often theorized that the legitimacy of courts does not reside in the positive consequences they generate, but in the independence and impartiality of judicial systems (Franck 1990). Likewise, it is frequently argued that citizens and parties accept the outcomes of democratic elections, even when these go against their self-interests, because of the fairness of the procedure (Tyler 1990). Consistent with this notion, recent work in comparative politics evaluates the legitimacy-generating capacity of alternative forms of decision-making arrangements (Esaiasson et al. 2012; de Fine Licht et al. 2014). We extend this expectation to global governance, suggesting that IOs' perceived conformance to procedural ideals influences audiences' legitimacy beliefs.

In addition, how well IOs measure up to procedural standards can be expected to influence patterns of legitimation and delegitimation. When IOs fall short of widely recognized procedural standards, this creates an opportunity for opponents to delegitimize the IO with reference to these limits. For instance, dissatisfaction with the decision-making modes of the WTO, the IMF, and the World Bank has been a prominent driver of the delegitimation of these IOs (O'Brien et al. 2000; Della Porta and Tarrow 2005). Social movements have condemned the large economic multilaterals for being closed, opaque, and undemocratic, while emerging powers have criticized them for not adequately reflecting the economic, political, and demographic balance in the world (Stephen and Zürn forthcoming). Other IOs frequently contested on procedural grounds include the EU, often diagnosed with a democratic deficit, and the UN, where the decision-making arrangements of the Security Council are a powerful magnet of criticism (Hurd 2007; Binder and Heupel 2015).

When IOs do not live up to expected procedural standards and are contested on those grounds, this typically generates efforts by the IO and its allies to defend the organization. Apart from efforts that respond to the criticism in question, IOs may seek to boost their legitimacy by invoking alternative legitimation narratives, referring to their strengths in meeting other procedural and performance standards. For instance, when the WTO, the EU, and the IMF were criticized for their democratic procedural shortcomings, the WTO liberalized its arrangements for civil society participation, the EU expanded the powers of the European Parliament, and the IMF introduced new transparency policies. 


\subsection{Performance}

The notion that performance matters for legitimacy features prominently in the study of domestic political institutions. As Newton and Norris $(2000,61)$ argue, "[g]overnment institutions that perform well are likely to elicit the confidence of citizens; those that perform badly or ineffectively generate feelings of distrust and low confidence." In IR, it is a common claim that IOs historically have earned their legitimacy through the collective benefits they have produced for states and societies. Lindberg and Scheingold (1970) famously spoke of a state of "permissive consensus" in Europe, where populations enjoyed the fruits of cooperation and supported its broad goals, while taking little concrete interest in the process of integration. Likewise, Scharpf (1999), pessimistic of the EU's capacity to gain legitimacy through democratic procedures, emphasizes the need for the organization to gain legitimacy through its contribution to problem-solving. Recent research on IOs such as the UN, the WTO, the IMF, and the EU suggests that citizens' perceptions of IO problem solving still constitute a strong force for legitimacy (Ecker-Ehrhardt 2012; Armingeon and Ceka 2014; Dellmuth and Tallberg 2015). More generally, functional accounts of international cooperation assume that states and their domestic constituencies support IOs' authority because of the collective benefits they generate (Keohane 1984).

How well IOs perform can also be expected to influence patters of legitimation. When decisions fall short of widely held expectations, this opens up opportunities to contest an IO's legitimacy. For instance, the economic crisis in the Eurozone from 2009 to 2015 gave additional ammunition to those political parties and movements that contested the EU and its policies. Similarly, the mixed historical success of the IMF's adjustment programs has exposed the organization to extensive criticism from social movements that wish to see the IO undermined and replaced. Sometimes, it is not so much the ineffectiveness of the organization as its distributive profile that generates contestation. For instance, the high share of Africans among the individuals prosecuted by the ICC has been used by several African governments to delegitimize the court.

When IOs fail to deliver and are criticized on those grounds, this is typically met with legitimation, aimed at regaining the confidence of audiences. As in the case of procedural deficits, we expect these efforts to follow a compensatory logic where IOs and their defenders broaden the narratives invoked to legitimize the organization. For instance, when the IMF suffered massive criticism for its handling of the 1997 Asian crisis, the organization embarked on a strategy of legitimation that included emphasizing and strengthening its democratic qualities and consideration of social and environmental issues (Gronau and Schmidtke 2015). Likewise, when the Economic Community of West African States (ECOWAS) was widely criticized for intervening in the domestic affairs of member states in the 1990s, the IO sought to re-establish its legitimacy by promoting a new strong regional intervention norm (Ba 2013).

\subsection{Legitimation process}

Moving to the next step in the framework, we expect the legitimation process to affect audiences' legitimacy beliefs. Legitimation and delegitimation practices intend to convince audiences of the merits or demerits of IOs in meeting procedural and performance standards. It is a core expectation of the framework that audiences are 
receptive to communication that invokes such standards. If individuals care about the procedures and performances of IOs, then legitimation practices that target these features should resonate with audiences and affect legitimacy beliefs.

We expect three features of the legitimation process to shape the likelihood of success. These expectations follow logically from the framework's emphasis on intensity, tone, and narratives as central properties of the legitimation process. These expectations are distinct from those of alternative perspectives that do not assign causal importance to the legitimation process and do not theorize the conditions under which it is likely to impact legitimacy beliefs.

To begin with, we expect the intensity of legitimation to matter for its impact on legitimacy beliefs. When citizens more frequently hear that the EU, for instance, undermines national sovereignty, wastes public funds, and causes a flood of migrants to their country, they are more likely to be affected in their beliefs about the IO. This expectation ties in with research showing that the loudest messages in a setting of competing messages have the greatest impact on public opinion, and that communication has to be repeated for its effects not to fade over time (Chong and Druckman 2010). In Zaller's $(1992,311)$ words, citizens "are blown about by whatever current of information manages to develop with the greatest intensity." This suggests that more frequently communicated legitimation or delegitimation claims would be more influential than less frequently communicated claims.

In addition, we expect the evaluative tone of communicated messages to matter. Negative messages (delegitimation) are likely more effective in shaping attitudes than positive messages (legitimation). This expectation is anchored in prospect theory (Kahneman and Tversky 1979), which proposes that people weigh potential losses more heavily than gains, and in psychological research, which establishes that bad emotions weigh more heavily on opinions than good emotions (Baumeister et al. 2001). Empirically, there is some evidence that negative elite messages indeed have stronger effects than positive messages in shaping public opinion on European and global governance (Maier et al. 2012; Dellmuth and Tallberg).

Finally, we expect narratives to be varyingly successful in influencing audiences' legitimacy beliefs depending on their strength in relation to existing attitudes. In line with political communication research, we posit that the strength of a message is contextual and may depend on several factors, including the credibility of the source, the resonance with consensus values, and the fit with deeply held prior beliefs (Druckman 2001; Chong 2000; Brewer 2001).

\section{Methods}

As a product of internal processes of cognition and recognition, legitimacy is less readily observable than many other phenomena in world politics, such as wars and treaties. In this special issue, we deal with this challenge through a complementary set of advanced methods. While several of these methods have been used successfully in other research traditions, many are novel to the study of legitimacy and legitimation in global governance. Together, they make these central but complex concepts in social theory empirically accessible. In addition, a common element in the special issue, which sets it apart from most existing research, is a comparative approach to the study 
of legitimacy and legitimation. The articles map and explain patterns in the legitimacy and legitimation of IOs over time, across organizations, or across countries. As a result, they allow us to move from impressions of legitimacy and legitimation in specific contexts to broader generalizations about patterns and explanations.

More specifically, we draw on methods developed in three complementary research traditions (see also Schmidtke and Schneider 2012). First, we measure and analyze legitimacy beliefs through surveys and survey experiments. Surveys allow researchers to assess how legitimacy beliefs vary over time, across organizations, and across relevant subsets of their audiences (Caldeira and Gibson 1995; Johnson 2011; EckerEhrhardt 2012; Bernauer and Gampfer 2013; Dellmuth and Tallberg 2015; Schlipphak 2015). For this purpose, IR scholars can build on a tradition in comparative politics of using trust or confidence in political institutions as a proxy for legitimacy beliefs (Caldeira and Gibson 1992; Gibson et al. 2003; Bühlmann and Kunz 2011; Norris 2011). Compared to alternative methods, the strength of surveys is the capacity to measure legitimacy beliefs at the individual level and to aggregate these data into representative samples amenable to quantitative analysis. In recent years, survey experiments have emerged as a prominent further development of this method. Survey experiments allow researchers to control for confounding factors so as to isolate the effect of different treatments (e.g., frames or cues) on legitimacy beliefs.

In this special issue, two contributions make use of survey experiments to analyze legitimacy beliefs. Anderson et al. (2018) evaluate in an experimental design whether and how institutional features of global climate governance influence perceptions of legitimacy. Similarly, Nielson et al. (2019) use three survey experiments - one in Kenya and two global - to evaluate what attributes of election monitoring organizations yield legitimacy in the eyes of domestic NGOs.

Second, we measure and analyze legitimation and delegitimation through data on political communication. Discursive legitimation and delegitimation of IOs take place in multiple arenas, ranging from institutional arenas (IOs themselves, national parliaments) to intermediate arenas (political parties, NGOs, media), and citizen arenas (work place, kitchen table) (Schmidtke and Schneider 2012). Different forms of content analysis are the favored method for getting at the intensity, tone, and narratives of legitimation and delegitimation discourses (Binder and Heupel 2015; Hurrelmann and Schneider 2015; Rauh and Bödeker 2016; Dingwerth et al. forthcoming). To the extent that (semi-)automated content analysis can further improve in validity and reliability, it opens up an extremely efficient means to study political communication on a scale previously unattainable.

In the special issue, one contribution builds on political communication data to explore legitimation and delegitimation processes. Henning Schmidtke (2018) explains variation in the legitimation and delegitimation of IOs based on a large-scale mapping of discursive statements in newspaper media in four countries over an extended time period.

Third, we study the political behavior of state and societal actors for evidence on both the legitimacy and legitimation of IOs. In recent years, data on citizen and NGO contestation of IOs have featured prominently in work on politicization and opposition in global governance (della Porta and Tarrow 2005; Zürn et al. 2012). Researchers have also begun to map the behavior of IOs as a way of identifying institutional legitimation practices (Tallberg et al. 2013; Zaum 2013; Grigorescu 2015; Rittberger and Schroeder 
2016). Potential behavioral indicators of legitimacy, legitimation, and delegitimation include participation in protest events, voting in transnational elections, IO adoption of institutional reforms, and IO establishment of public relations offices. Compared to alternative methods, the strength of behavioral data is the ability to get at nondiscursive practices of legitimation and delegitimation.

In the special issue, one contribution explores political behavior for data on legitimation. Rocabert et al. (2018) map and analyze the creation by IOs of international parliamentary institutions as an institutional legitimation practice, combining large-n analysis and case studies.

\section{Organization of the special issue}

The remainder of this special issue is organized in two parts. The core of the volume is four empirical articles offering systematic, comparative analyses of legitimacy and legitimation. These articles are informed by the theoretical framework outlined in this introduction, but they also go beyond to develop and assess alternative explanations. The first two articles focus on institutional and discursive legitimation, respectively, mapping and explaining patterns over time and across IOs. The subsequent two articles explore sources of IO legitimacy among citizens and NGO representatives in two fields - climate governance and election monitoring. The volume concludes with two commentaries that offer an external perspective on the contributions of the project. While appreciating the efforts of the project, both call for greater attention to the politics of legitimacy and legitimation at domestic and international levels.

Rocabert et al. (2018) explore the rise of international parliamentary institutions (IPIs) in world politics. They claim that standard functionalist theories of international cooperation cannot explain the creation and design of IPIs. Instead, they argue that the adoption of IPIs reflects an institutional legitimation strategy, mainly driven by the type of authority of IOs. IPI creation is a particularly prominent legitimation strategy when IOs have broad policy scope. This relationship holds independently of how democratic IO memberships are. They demonstrate the explanatory power of this argument through a statistical analysis of IPIs in 73 IOs, as well as case studies of IPI creation in the ECOWAS and the Pacific Islands Forum (PIF).

Schmidtke (2018) maps and explains central patterns of legitimation and delegitimation of IOs in media discourse. While there is an absence of comparative and longitudinal studies in existing research, this contribution systematically assesses the intensity, tone, and narratives of legitimation over time (1998-2013), across IOs (EU, UN, G8), and across countries (Germany, Switzerland, UK, US) by analyzing around 6500 evaluative statements. The article demonstrates that IOs with more extensive authority are subject to more intense legitimation and delegitimation. The findings also defy the expectation of growing legitimation and delegitimation over time, instead pointing to ups and downs resulting from authority shifts, crises, and other salient events. The article further demonstrates that media discourse on IOs is predominantly negative in tone.

Anderson et al. (2018) assess whether and how institutional features of global climate governance affect the legitimacy beliefs of US and German citizens. They find that the procedures and performance of global climate governance influence legitimacy 
beliefs significantly. Governance arrangements that are perceived as less democratic and effective are also considered less legitimate. In addition, individual priors, such as climate concern and cognitive mobilization, shape citizens' legitimacy beliefs. People who believe in the need for strong climate governance do not question the legitimacy of intrusive arrangements. The link between authority and legitimacy is therefore weaker in this case.

Finally, Nielson et al. (2019) examine the sources of legitimacy for election observation organizations, IOs, and NGOs. They assess two perspectives: one privileging objective substantive features of election monitoring organizations in terms of procedures, performances, and goals; and one privileging heuristic mechanisms of isomorphism and prominence. Three survey experiments provide limited evidence of NGOs being responsive to statements priming the substantive features of election observation organizations. Instead, the findings indicate that NGO representatives rely on isomorphism and prominence when forming legitimacy beliefs. When judging hypothetical observation organizations, NGOs found non-governmental groups like themselves to be more legitimate than IOs. However, when evaluating real-world organizations, NGOs rated famous IOs as significantly more legitimate. These findings suggest that legitimacy beliefs are formed in processes in which organizations' substantive institutional features carry limited weight.

In the first commentary, Ian Hurd (2018) challenges the special issue for promoting a perspective on legitimacy in global governance that de-emphasizes politics and power. In his view, the volume rests on a combination of a standard liberal model of legitimacy and methodological behavioralism that makes it harder to see the most relevant forms of contestation surrounding legitimacy. In spite of its consideration of both legitimation and delegitimation practices, the special issue remains, in Hurd's view, centered on explaining why people find IOs legitimate, without asking why they might reasonably oppose them. In his view, this perspective on legitimacy diverts attention away from the power and domination inherent in the rules actors are asked to obey, and downplays dissent, disagreement, and contestation.

In the second commentary, Hooghe et al. (2018) criticize the special issue for neglecting the domestic ideological setting in which legitimacy beliefs vis-à-vis IOs are formed. They argue that legitimacy beliefs and legitimation practices are a product not only of IO characteristics, but also of domestic ideological trends that transcend specific IOs. In particular, they discuss the origins and manifestations of the criticism against IOs on the radical left and radical right. The first supports international cooperation in principle, but contends that many IOs in practice give primacy to economic exchange while neglecting environmental and distributional effects. The second criticizes global governance both in principle and in practice because of its detrimental effects on national sovereignty and cultural homogeneity. Hooghe et al. further suggest that the prominence of these ideological critiques of IOs is conditioned by the nature of IOs' authority.

\section{Conclusion}

The aim of this special issue is to further a better understanding of when, how, and why IOs gain, sustain, and lose legitimacy in world politics. This is an urgent social 
scientific challenge, but also a task of great political relevance. There are strong signs that the issue of IO legitimacy is at the core of a new political cleavage in many societies (Hooghe et al. 2018; de Wilde et al. forthcoming). This cleavage pits cosmopolitans favoring open borders, universal rights, and strong multilateral institutions against nationalists defending closed borders, popular sovereignty, and the will of the "silent majority." The Brexit vote in 2016, the election of Donald Trump as US president in 2017, and the general rise in anti-globalist populism all suggest that the legitimacy of IOs cannot be taken for granted. We conclude this introductory article by briefly summarizing what we have learned so far and what we consider important next steps for this research agenda.

The contribution of this special issue comes in three parts. First, we introduce a novel theoretical framework for studying legitimacy and legitimation in world politics. According to this framework, legitimacy beliefs are the outcome of a social process in which legitimation and delegitimation shape audiences' perceptions of IO features they care about. Second, we advance a positive approach to legitimacy and legitimation that seeks to make these classic concepts in social theory empirically tractable through advanced scientific methods and rich empirical data. Informed by this approach, the articles seek to systematically map and explain patterns in the legitimacy and legitimation of IOs. Third, the contributions to this special issue produce original and intriguing empirical findings. These findings are broadly supportive of our basic theoretical expectations, but they also suggest important extensions.

To begin with, the contributions suggest that legitimation and delegitimation patterns indeed are shaped by the institutional features of IOs. Rocabert et al. (2018) demonstrate how IOs with broader institutional authority are more likely to legitimize themselves through the creation of parliamentary assemblies, but also how the democratic composition of IOs matters for this type of behavioral legitimation. Similarly, Schmidtke (2018) shows how IOs with greater institutional authority are subject to more intense legitimation and delegitimation in the media, but also how patterns in such discursive legitimation partly are driven by exogenous events. These results combine well with other recent findings highlighting how authority drives legitimation and contestation in global governance (Zürn 2018), and how IOs increasingly engage in democratic self-legitimation (Dingwerth et al. forthcoming).

Turning to legitimacy beliefs as outcome, the contributions highlight the combined importance of individual priors, legitimation processes, and IO features. Anderson et al. (2018) demonstrate how procedure and performance in global environmental governance affect its legitimacy among citizens, but also how strong priors about the necessity of environmental action can trump other considerations. Likewise, Nielson et al. (2019) highlight the role of heuristics in the formation of legitimacy beliefs, including the familiarity of IOs due to earlier communication about these organizations. These results tie in well with other recent research underlining the importance of elite communication and heuristics in shaping citizens' legitimacy beliefs (Ares et al. 2017; Dellmuth and Tallberg).

What are next steps for this research agenda as we look beyond this special issue? We wish to highlight three areas. First, there is scope for additional theoretical refinement and empirical testing of the relationships we have theorized. As a first effort to explore how institutional features of IOs affect legitimation processes and legitimacy beliefs, this volume probably raises more questions than it settles. Integrating complex 
concepts such as authority and legitimacy into a framework for empirical testing naturally raises questions about measurement that remain relevant. The contributions to this special issue can only examine some of the relationships we discuss, leaving others ripe for exploration. We also see a potential for evaluating the expected associations in other empirical contexts and based on other methods.

Second, we need to consider other factors potentially shaping the legitimacy and legitimation of IOs. Our framework takes institutional features of IOs as the analytical starting point and theorizes their effects in a context of individual and societal factors. Yet there are indications - in this volume and elsewhere - that individual and societal factors demand more thorough attention in and of themselves (Tallberg et al. 2018). Individual priors and predispositions appear to matter profoundly for the formation of legitimacy beliefs (Dellmuth and Tallberg forthcoming; Anderson et al. 2018; Nielson et al. 2019), just as domestic conditions in IO member states appear to matter for legitimation patterns, as underlined by Hooghe et al. (2018) in their commentary. We also see a potential to expand our framework in two other directions, bracketed in the current version, by considering feedback effects from legitimation processes and legitimacy beliefs to the institutional design of IOs, and by exploring the relationship between citizen and elite opinion toward IOs.

Finally, future research should take on the next step in the causal chain by systematically examining the consequences of legitimacy. While existing research suggests that legitimacy matters, as described in the beginning of this article, we know less about the conditions and mechanisms through which such effects come about (Sommerer and Agné 2018). This gap also ties in with Hurd's (2018) criticism of this special issue for neglecting the distributional implications of legitimacy and legitimation in global governance. When and how do higher or lower levels of legitimacy among member governments, stakeholder groups, and the general public change the ways that IOs operate and affect their surroundings? Addressing this question requires attention to the multiple types of outcomes that legitimacy may affect - from the authority, resources, and ambitions of IOs to the implementation and impact of their policies around the world.

Acknowledgements As a framing paper for the special issue, this article has benefited tremendously from input by the participants in the larger project. We are grateful to Brile Anderson, Thomas Bernauer, Loriana Crasnic, Lisa Dellmuth, Klaus Dingwerth, Susan Hyde, Aya Kachi, Judith Kelley, Dan Maliniak, Dan Nielson, Brittany Parowski, Christian Rauh, Jofre Rocabert, Frank Schimmelfennig, Henning Schmidtke, Mike Tierney, Tobias Weise, and Thomas Winzen for comments at three project workshops in Berlin and Stockholm. In addition, we would like to thank Bob Keohane and Mathias Koenig-Archibugi for very valuable comments on an early draft.

Publisher's Note Springer Nature remains neutral with regard to jurisdictional claims in published maps and institutional affiliations.

\section{References}

Anderson, B., Bernauer, T., \& Kachi, A. (2018) Does international pooling of authority affect the perceived legitimacy of global governance? The Review of International Organizations, https://doi.org/10.1007 /s11558-018-9341-4.

Arendt, H. (1956). Authority in the Twentieth Century. Review of Politics, 18(4), 403-417. 
Ares, M., Ceka, B., \& Kriesi, H. (2017). Diffuse support for the European Union: Spillover Effects of the Politicization of the European Integration Process at the Domestic Level. Journal of European Public Policy, 24(8), 1091-1115.

Armingeon, K., \& Ceka, B. (2014). The Loss of Trust in the European Union during the Great Recession since 2007: The Role of Heuristics from the National Political System. European Union Politics, 15(1), 82107.

Ashforth, B. E., \& Gibbs, B. W. (1990). The Double-Edge of Organizational Legitimation. Organization Science, 1(2), 177-194.

Avant, D. D., Finnemore, M., \& Sell, S. K. (Eds.). (2010). Who Governs the Globe? New York: Cambridge University Press.

Ba, A. D. (2013). The Association of Southeast Asian Nations: Between Internal and External Legitimacy. In D. Zaum (Ed.), Legitimating International Organizations (pp. 132-161). Oxford: Oxford University Press.

Bäckstrand, K., \& Söderbaum, F. (2018). Legitimation and Delegitimation in Global Governance: Discursive, Institutional, and Behavioral Practices. In J. Tallberg, K. Bäckstrand, \& J. A. Scholte (Eds.), Legitimacy in Global Governance: Sources, Processes, and Consequences (pp. 101-118). Oxford: Oxford University Press.

Banchoff, T. F., \& Smith, M. P. (Eds.). (1999). Legitimacy and the European Union: The Contested Polity. London: Routledge.

Barker, R. (2001). Legitimating Identities: The Self-presentations of Rulers and Subjects. Cambridge: Cambridge University Press.

Barnett, M. N., \& Finnemore, M. (1999). The Politics, Power, and Pathologies of International Organizations. International Organization, 53(4), 699-732.

Baumeister, R. F., Bratslavsky, E., Finkenauer, C., \& Vohs, K. D. (2001). Bad Is Stronger Than Good. Review of General Psychology, 5(4), 323-370.

Beetham, D. (1991). The Legitimation of Power. Atlantic Highlands, NJ: Humanities Press International.

Bernauer, T., \& Gampfer, R. (2013). Effects of Civil Society Involvement on Popular Legitimacy of Global Environmental Governance. Global Environmental Change, 23(2), 439-449.

Bernstein, S. (2011). Legitimacy in Intergovernmental and Non-state Global Governance. Review of International Political Economy, 18(1), 17-51.

Binder, M., \& Heupel, M. (2015). The Legitimacy of the UN Security Council: Evidence from Recent General Assembly Debates. International Studies Quarterly, 59(2), 238-250.

Bogdandy, A., von Wolfrum, R., Bernstorff, J., von Dann, P., \& Goldmann, M. (Eds.). (2010). The Exercise of Public Authority by International Institutions. Advancing International Institutional Law. Heidelberg: Springer.

Booth, J. A., \& Seligson, M. A. (2009). The Legitimacy Puzzle in Latin America: Political Support and Democracy in Eight Nations. Cambridge: Cambridge University Press.

Brassett, J., \& Tsingou, E. (2011). The Politics of Legitimate Global Governance. Review of International Political Economy, 18(1), 1-16.

Brewer, P. R. (2001). Value Words and Lizard Brains: Do Citizens Deliberate About Appeals to Their Core Values? Political Psychology, 22, 45-64.

Buchanan, A., \& Keohane, R. O. (2006). The Legitimacy of Global Governance Institutions. Ethics \& International Affairs, 20(4), 405-437.

Bühlmann, M., \& Kunz, R. (2011). Confidence in the Judiciary: Comparing the Independence and Legitimacy of Judicial Systems. West European Politics, 34(2), 317-345.

Caldeira, G. A., \& Gibson, J. L. (1992). The Etiology of Public Support for the Supreme Court. American Journal of Political Science, 36(3), 635-664.

Caldeira, G. A., \& Gibson, J. L. (1995). The Legitimacy of the Court of Justice in the European Union: Models of Institutional Support. American Journal of Political Science, 89(2), 356-376.

Carr, E. H. (1946). The Twenty-Years Crisis (2nd ed.). London: Macmillan.

Chalmers, A. W., \& Dellmuth, L. M. (2015). Fiscal Redistribution and Public Support for European Integration. European Union Politics, 16(3), 386-407.

Chayes, A., \& Chayes, A. H. (1998). The New Sovereignty: Compliance with International Regulatory Agreements. Cambridge, MA: Harvard University Press.

Checkel, J. T. (2001). Why Comply? Social Learning and European Identity Change. International Organization, 55(3), 553-588.

Chong, D. (2000). Rational Lives: Norms and Values in Politics and Society. Chicago: University of Chicago Press.

Chong, D., \& Druckman, J. N. (2007). Framing Theory. Annual Review of Political Science, 10(1), $103-126$. 
Chong, D., \& Druckman, J. N. (2010). Dynamic Public Opinion: Communication Effects over Time. American Political Science Review, 104(4), 663-680.

Clark, I. (2005). Legitimacy in International Society. Oxford: Oxford University Press.

Claude, I. L. (1966). Collective Legitimization as a Political Function of the United Nations. International Organization, 20(3), 367-379.

Dahl, R. A. (1989). Democracy and its Critics. New Haven, CT: Yale UP.

Dahl, R. A. (1999). Can International Organizations be Democratic? A Skeptic's View. In I. Shapiro \& C. Hacker-Cordon (Eds.), Democracy's Edges (pp. 19-36). Cambridge: Cambridge University Press.

Dahl, R. A., \& Lindblom, C. (1992). Politics, Markets, and Welfare. 2nd edition. New Brunswick, NJ: Transaction Press.

de Fine Licht, J., Naurin, D., Esaiasson, P., \& Gilljam, M. (2014). When Does Transparency Generate Legitimacy? Experimenting on a Context-Bound Relationship. Governance, 27(1), 111-134.

de Wilde, P., \& Zürn, M. (2012). Can the Politicization of European Integration Be Reversed? Journal of Common Market Studies, 50(S1), 137-153.

de Wilde, P., Koopmans, R., Merkel, M., Strijbs, O., \& Zürn, M. (forthcoming) Struggle Over Border. The Political Sociology of Cosmopolitanism and Communitarianism. Cambridge: Cambridge University Press

della Porta, D., \& Tarrow, S. (Eds.). (2005). Transnational Protest and Global Activism. Lanham: Rowman \& Littlefield.

Dellmuth, L. M. (2018). Individual Sources of Legitimacy Beliefs: Theory and Data. In J. Tallberg, K. Bäckstrand, \& J. A. Scholte (Eds.), Legitimacy in Global Governance: Sources, Processes, and Consequences (pp. 37-55). Oxford: Oxford University Press.

Dellmuth, L. M., \& Tallberg, J. (2015). The Social Legitimacy of International Organisations: Interest Representation, Institutional Performance, and Confidence Extrapolation in the United Nations. Review of International Studies, 41(3), 451-475.

Dellmuth, L. M., \& Tallberg, J. (forthcoming). Why National and International Legitimacy Are Linked: Social Trust as an Antecedent Factor. Review of International Organizations.

Dingwerth, K., Witt, A., Lehmann, I., Reichel, E., \& Weise, T. (forthcoming). International Organizations under Pressure: Legitimating Global Governance in Changing Times. Oxford: Oxford University Press.

Druckman, J. N. (2001). On the Limits of Framing Effects: Who Can Frame? Journal of Politics, 63, 10411066.

Easton, D. (1975). A Re-Assessment of the Concept of Political Support. British Journal of Political Science, $5(4), 435-457$.

Ecker-Ehrhardt, M. (2012). Cosmopolitan Politicization: How Perceptions of Interdependence Foster Citizens' Expectations in International Institutions. European Journal of International Relations, 18(3), 481-508.

Ecker-Ehrhardt, M. (2018). Self-legitimation in the Face of Politicization: Why International Organizations Centralized Public Communication. Review of International Organizations, 13(4), 519-546.

Eisentraut, S. (2016). Talking Global Democracy. The Democratic Narrative in the Reform Debates of International Organizations. Ph.D. In Thesis. Berlin: Berlin Grauate School of Sociel Sciences.

Elster, J. (Ed.) (1986). Rational Choice: New York, NY: New Yourk University Press.

Esaiasson, P., Gilljam, M., \& Persson, M. (2012). Which Decision-making Arrangements Generate the Strongest Legitimacy Beliefs? Evidence from a Randomised Field Experiment. European Journal of Political Research, 51(6), 785-808.

Finnemore, M. (2009). Legitimacy, Hypocrisy, and the Social Structure of Unipolarity. World Politics, 61(1), 58-85.

Forst, R. (2015). Normativität und Macht: Zur Analyse sozialer Rechtfertigungsordnungen. Berlin: Suhrkamp.

Franck, T. M. (1990). The Power of Legitimacy among Nations. Oxford: Oxford University Press.

Gabel, M. (1998). Public Support for European Integration: An Empirical Test of Five Theories. Journal of Politics, 60(2), 333-354.

Gibson, J. L., Caldeira, G. A., \& Spence, L. K. (2003). Measuring Attitudes toward the United States Supreme Court. American Journal of Political Science, 47(2), 354-367.

Goldsmith, J. L., \& Posner, E. A. (2005). The Limits of International Law. Oxford: Oxford University Press.

Gregoratti, C., \& Uhlin, A. (2018). Civil Society Protest and the (De)Legitimation of Global Governance Institutions. In J. Tallberg, K. Bäckstrand, \& J. A. Scholte (Eds.), Legitimacy in Global Governance: Sources, Processes, and Consequences (pp. 134-152). Oxford: Oxford University Press.

Grigorescu, A. (2007). Transparency of Intergovernmental Organizations: The Roles of Member States, International Bureaucracies and Nongovernmental Organizations. International Studies Quarterly, 51(3), 625-648. 
Grigorescu, A. (2015). Democratic Intergovernmental Organizations? Normative Pressures and DecisionMaking Rules. New York: Cambridge University Press.

Gronau, J., \& Schmidtke, H. (2015). The Quest for Legitimacy in World Politics - International Institutions' Legitimation Strategies. Review of International Studies, 42(3), 535-557.

Habermas, J. (1976). Legitimation Crisis. London: Heinemann.

Habermas, J. (1996). Between Facts and Norms: Contributions to a Discourse Theory of Law and Democracy. Cambridge, Mass. MIT Press.

Habermas, J. (1998). Die postnationale Konstellation: Politische Essays. Frankfurt am Main: Suhrkamp.

Halliday, T. C., Block-Lieb, S., \& Carruthers, B. G. (2010). Rhetorical Legitimation: Global Scripts as Strategic Devices of International Organizations. Socio-Economic Review, 8(1), 77-112.

Harteveld, E., van der Meer, T., \& de Vries, C. E. (2013). In Europe We Trust? Exploring Three Logics of Trust in the European Union. European Union Politics, 14(4), 542-565.

Hawkins, D. G., Lake, D. A., Nielson, D. N., \& Tierney, M. J. (Eds.). (2006). Delegation and Agency in International Organizations. Cambridge: Cambridge University Press.

Held, D., \& Koenig-Archibugi, M. (Eds.). (2005). Global Governance and Public Accountability. Oxford: Blackwell.

Heupel, M., \& Zürn, M. (Eds.). (2016). International Organisations and Human Rights. Explaining Limitations of International Authority. Cambridge: Cambridge University Press.

Hooghe, L., \& Marks, G. (2005). Calculation, Community and Cues: Public Opinion on European Integration. European Union Politics, 6(4), 419-443.

Hooghe, L., \& Marks, G. (2009). A Postfunctionalist Theory of European Integration: From Permissive Consensus to Constraining Dissensus. British Journal of Political Science, 39(1), 1-23.

Hooghe, L., Marks, G., Lenz, T., Bezuijen, J., Ceka, B., \& Derderyan, S. (2017). Measuring International Authority: A Postfunctionalist Theory of Governance. Oxford: Oxford University Press.

Hooghe, L., Lenz, T., \& Marks, G. (2018) Contested world order: The delegitimation of international governance. The Review of International Organizations, https://doi.org/10.1007/s11558-018-9334-3.

Hurd, I. (1999). Legitimacy and Authority in International Politics. International Organization, 53(2), 379408.

Hurd, I. (2007). After Anarchy: Legitimacy and Power in the United Nations Security Council. Princeton, N.J. Princeton University Press.

Hurd, I. (2018) Legitimacy and contestation in global governance: Revisiting the folk theory of international institutions. The Review of International Organizations https://doi.org/10.1007/s11558-018-9338-z.

Hurrelmann, A., \& Schneider, S. (Eds.). (2015). The Legitimacy of Regional Integration in Europe and the Americas. Basingstoke: Palgrave.

Ikenberry, G. J. (2001). After Victory. Institutions, Strategic Restraint, and the Rebuilding of Order after Major Wars. Princeton, NJ: Princeton University Press.

Inglehart, R., \& Welzel, C. (2005). Modernization, Cultural Change, and Democracy: The Human Development Sequence. Cambridge: Cambridge University Press.

Johnson, T. (2011). Guilt by Association: The Link between States' Influence and the Legitimacy of Intergovernmental Organizations. Review of International Organizations, 6(1), 57-84.

Johnson, T. (2014). Organizational Progeny. Why Governments are Losing Control over the Proliferating Structures of Global Governance. Oxford: Oxford University Press.

Kahneman, D., \& Tversky, A. (1979). Prospect Theory: An Analysis of Decision under Risk. Econometrica, 47(2), 263-292.

Keohane, R. O. (1984). After Hegemony. Cooperation and Discord in the World Political Economy. Princeton, NJ: Princeton University Press.

Keohane, R. O. (2006). The Contingent Legitimacy of Multilateralism. In E. Newman, R. Thakur, \& J. Tirman (Eds.), Multilateralism under Challenge? Power, Institutional Order, and Structural Change (pp. 56-76). Tokyo: United Nations University Press.

Kojéve, A. (2014). The Notion of Authority. London: Verso.

Krasner, S. D. (1999). Sovereignty: Organized Hypocrisy. Princeton, NJ: Princeton University Press.

Lake, D. A. (2007). Escape from the State of Nature: Authority and Hierarchy in World Politics. International Security, 32(1), 47-79.

Lake, D. A. (2010). Rightful Rules: Authority, Order, and the Foundations of Global Governance. International Studies Quarterly, 54(3), 587-613.

Lake, D. A. (2015). Why Is It So Damned Hard to Operationalize Authority? Reflections on an Impossible Construct. Paper prepared for the International Authority Workshop, Berlin, December, 10-11, 2015.

Lenz, T., Bezuijen, J., Hooghe, L., \& Marks, G. (2015). Patterns of International Authority: Task Specific vs. General Purpose. Politischen Vierteljahresschrift Special issue, 49, 131-156. 
Lindberg, L. N., \& Scheingold, S. A. (1970). Europe's Would-Be Polity. Patterns of Change in the European Community. Englewood Cliffs, NJ: Prentice Hall.

Lindblom, C. E. (1977). Politics and Markets: The World's Political-Economic Systems. New York, NY: Basic Books.

Lipset, S. M. (1960). Political Man: The Social Basis of Politics. New York: Doubleday \& Company.

MacDonald, T. (2012). Citizens or Stakeholders? Exclusion, Equality and Legitimacy in Global Stakeholder Democracy. In D. Archibugi, M. Koenig-Archibugi, \& R. Marchetti (Eds.), Global Democracy: Normative and Empirical Perspectives (pp. 47-68). Cambridge: Cambridge University Press.

Maier, M., Adam, S., \& Maier, J. (2012). The Impact of Identity and Economic Cues on Citizens' EU Support: An Experimental Study on the Effects of Party Communication in the Run-Up to the 2009 European Parliament Elections. European Union Politics, 13(4), 580-603.

Martin, L. L. (2000). Democratic Commitments: Legislatures and International Cooperation. Princeton, N.J. Princeton University Press.

Meyer, J. W., \& Rowan, B. (1977). Institutionalized Organizations: Formal Structure as Myth and Ceremony. American Journal of Sociology, 83(2), 340-363.

Morgenthau, H. J. (1948). Politics Among Nations. The Struggle for Power and Peace. New York, NY: Alfred A. Knopf.

Morse, J. C., \& Keohane, R. O. (2014). Contested Multilateralism. Review of International Organizations, 9(4), 385-412.

Newton, K., \& Norris, P. (2000). Confidence in Public Institutions: Faith, Culture or Performance? In S. J. Pharr \& R. D. Putnam (Eds.), Disaffected Democracies: What's Troubling the Trilateral Countries? (pp. 52-73). Princeton: Princeton University Press.

Nielson, D. L., Hyde, S. D., \& Kelley, J. (2019) The elusive sources of legitimacy beliefs: Civil society views of international election observers. The Review of International Organizations, https://doi.org/10.1007 /s11558-018-9331-6.

Norris, P. (2000). Global Governance \& Cosmopolitan Citizens. In J. S. Nye \& J. D. Donahue (Eds.), Governance in a Globalizing World (pp. 155-177). Washington, DC: Brookings Institution Press.

Norris, P. (2009). Confidence in the United Nations: Cosmopolitan and Nationalistic Attitudes. In Y. Esmer \& T. Pettersson (Eds.) The International System, Democracy, and Values (pp. 17-48). Uppsala: Acta Universitatis Upsaliensis.

Norris, P. (2011). Democratic Deficit: Critical Citizens Revisited. Cambridge: Cambridge University Press.

Nullmeier, F., Biegon, D., Nonhoff, M., Schmidtke, H., \& Schneider, S. (2010). Prekäre Legitimitäten: Rechtfertigung von Herrschaft in der postnationalen Konstellation. Campus: Frankfurt am Main.

O'Brien, R., Goetz, A. M., Scholte, J. A., \& Williams, M. (2000). Contesting Global Governance: Multilateral Institutions and Global Social Movements. Cambridge: Cambridge University Press.

Parsons, T. (1960). Structure and Process in Modern Societies. Glencoe, IL. Free Press.

Paterson, M. (2010). Legitimation and Accumulation in Climate Change Governance. New Political Economy, 15(3), 345-368.

Putnam, R. D. (1988). Diplomacy and Domestic Politics. The Logic of Two-Level Games. International Organization, 42(3), 427-460.

Rauh, C., \& Bödeker, S. (2016). Internationale Organisationen in der deutschen Öffentlichkeit - ein Text Mining Ansatz. In M. Lemke \& G. Wiedemann (Eds.) Text-Mining in den Sozialwissenschaften. Grundlagen und Anwendungen zwischen qualitativer und quantitativer Diskursanalyse. Wiesbaden: Springer VS.

Raz, J. (1990). Introduction. In J. Raz (Ed.), Authority (pp. 1-19). Oxford: Blackwell.

Reus-Smit, C. (2007). International Crises of Legitimacy. International Politics, 44(2), 157-174.

Risse, T., Ropp, S. C., \& Sikkink, K. (Eds.). (1999). The Power of Human Rights. International Norms and Domestic Change. Cambridge: Cambridge University Press.

Rittberger, B., \& Schroeder, P. (2016). The Legitimacy of Regional Institutions. In T. Börzel \& T. Risse (Eds.), Oxford Handbook of Comparative Regionalism (pp. 579-599). Oxford: Oxford University Press.

Rixen, T., \& Zangl, B. (2013). The Politicization of International Economic Institutions in US Public Debates. Review of International Organizations, 8(3), 363-387.

Rocabert, J., Schimmelfennig, F., Crasnic, L, \& Winzen, T. (2018) The rise of international parliamentary institutions: Purpose and legitimation. The Review of International Organizations, https://doi.org/10.1007 /s11558-018-9326-3.

Rohrschneider, R. (2002). The Democracy Deficit and Mass Support for an EU-Wide Government. American Journal of Political Science, 46(2), 463-475.

Rothstein, B. (2005). Social Traps and the Problem of Trust. Cambridge: Cambridge University Press.

Scharpf, F. W. (1999). Governing in Europe: Effective and Democratic? Oxford: Oxford University Press. 
Schlipphak, B. (2015). Measuring Attitudes toward Regional Organizations outside Europe. Review of International Organizations, 10(3), 351-375.

Schmidt, V. A. (2013). Democracy and Legitimacy in the European Union Revisited: Input, Output and 'Throughput'. Political Studies, 61(1), 2-22.

Schmidtke, H. (2018) Elite legitimation and delegitimation of international organizations in the media: Patterns and explanations. The Review of International Organizations, https://doi.org/10.1007/s11558018-9320-9.

Schmidtke, H., \& Schneider, S. (2012). Methoden der empirischen Legitimationsforschung: Legitimität als mehrdimensionales Konzept. In A. Geis, F. Nullmeier, \& C. Daase (Eds.), Der Aufstieg der Legitimitätspolitik. Rechtfertigung und Kritik politisch-ökonomischer Ordnungen (Special issue 40/27, Leviathan) (pp. 225-242). Baden-Baden: Nomos.

Scholte, J. A. (2018). Social Structure and Global Governance Legitimacy. In J. Tallberg, K. Bäckstrand, \& J. A. Scholte (Eds.), Legitimacy in Global Governance: Sources, Processes, and Consequences (pp. 75100). Oxford: Oxford University Press.

Scholte, J. A., \& Tallberg, J. (2018). Theorizing the Institutional Sources of Global Governance Legitimacy. In J. Tallberg, K. Bäckstrand, \& J. A. Scholte (Eds.), Legitimacy in Global Governance: Sources, Processes, and Consequences (pp. 56-74). Oxford: Oxford University Press.

Sommerer, T., \& Agné, H. (2018). Consequences of Legitimacy in Global Governance. In J. Tallberg, K. Bäckstrand, \& J. A. Scholte (Eds.), Legitimacy in Global Governance: Sources, Processes, and Consequences (pp. 153-168). Oxford: Oxford University Press.

Steffek, J. (2003). The Legitimation of International Governance: A Discourse Approach. European Journal of International Relations, 9(2), 249-275.

Stephen, M. D. (2015). “Can You Pass the Salt?” The Legitimacy of International Institutions and Indirect Speech. European Journal of International Relations, 21(4), 768-792.

Stephen, M. D., \& Zürn, M. (Eds.) (forthcoming). Contested World Orders. Rising Powers, Non-State Actors, and the Politics of Authority beyond the Nation-State. Oxford: Oxford University Press.

Suchman, M. C. (1995). Managing Legitimacy: Strategic and Institutional Approaches. The Academy of Management Review, 20(3), 571-610.

Tallberg, J., Sommerer, T., Squatrito, T., \& Jönsson, C. (2013). The Opening Up of International Organizations: Transnational Access in Global Governance. Cambridge: Cambridge University Press.

Tallberg, J., Sommerer, T., Squatrito, T., \& Jönsson, C. (2014). Explaining the Transnational Design of International Organizations. International Organization, 68(4), 741-774.

Tallberg, J., Bäckstrand, K., \& Scholte, J. A. (Eds.) (2018) Legitimacy in Global Governance: Sources, Processes, and Consequences. Oxford: Oxford University Press.

Tyler, T. (1990). Why People Obey the Law. New Haven, Conn. Yale University Press.

Uslaner, E. M. (2002). The Moral Foundations of Trust. Cambridge: Cambridge University Press.

Voeten, E. (2013). Public Opinion and the Legitimacy of International Courts. Theoretical Inquiries in Law, 14(2), 411-436.

Weber, M. (1922/1978). Economy and Society. Berkeley and Los Angeles: University of California Press.

Williams, B. A. O. (2005). In the Beginning was the Deed: Realism and Moralism in Political Argument. Princeton, NJ: Princeton University Press.

Zaller, J. R. (1992). The Nature and Origins of Mass Opinion. Cambridge: Cambridge University Press.

Zaum, D. (Ed.). (2013). Legitimating International Organizations. Oxford: Oxford University Press.

Zelli, F. (2018). Effects of Legitimacy Crises in Complex Global Governance. In J. Tallberg, K. Bäckstrand, \& J. A. Scholte (Eds.), Legitimacy in Global Governance: Sources, Processes, and Consequences (pp. 169188). Oxford: Oxford University Press.

Zürn, M. (2000). Democratic Governance beyond the Nation-State. The EU and Other International Institutions. European Journal of International Relations, 6(2), 183-221.

Zürn, M. (2004). Global Governance and Legitimacy Problems. Government and Opposition, 39(2), $260-287$.

Zürn, M. (2018). A Theory of Global Governance: Authority, Legitimacy, and Contestation. Oxford: Oxford University Press.

Zürn, M., \& Joerges, C. (Eds.). (2005). Law and Governance in Postnational Europe. Cambridge: Cambridge University Press.

Zürn, M., Binder, M., \& Ecker-Ehrhardt, M. (2012). International Authority and Its Politicization. International Theory, 4(1), 69-106. 